Г. М. Волинець

\title{
НУЛЬСУФІКСАЛЬНІ ДЕРИВАТИ НА ПОЗНАЧЕННЯ ЯВИЩ ПРИРОДИ ТА ФІЗИЧНИХ ЯВИЩ У СУЧАСНІЙ УКРАЇНСЫКІЙ МОВІ
}

Волинець Г. М. Нульсуфіксальні деривати на позначення явищ природи та фізичних явищ у сучасній українській мові.

У статті на матеріалі сучасної української мови розглядаються нульсуфіксальні похідні - назви явищ природи та фізичних явищ. Здійснено опис цих іменників, їхню семантику, кількісний вияв, функціонування нульсуфіксальних похідних у порівнянні 3 дериватами 3 матеріально вираженими суфіксами.

Ключові слова: нульовий суфікс, дериват, функції суфіксів, нульсуфіксація.

Волынец Г. Н. Нульсуффиксальные дериваты со значением явлений природы и физических явлений в современном украинском языке.

В статье на материале современного украинского языка исследуются нульсуффиксальные производные имена существительные со значением явлений природы и физических явлений. Осуществлено описание таких дериватов, их семантики, количество, а также функциональные 
возможности нульсуффикальных имен существительных по сравнению с производными с материально выраженными суффиксами.

Ключевые слова: нулевой суффикс, дериват, функции суффиксов, нулевая суффиксация.

Volynets G. M. Zero-suffix formation of the nouns with meaning of the phenomena of nature and physical phenomena in the modern Ukrainian language.

The derivatives with zero-suffix (with meaning of the phenomena of nature and physical phenomena) on the basis of modern Ukrainian language are represented in the article. The author described the derivatives with zero suffix, their semantic and number, their function in comparison with derivatives with others suffixes.

Key words: zero-suffix, derivative, functions of suffixes, zero-suffix derivation.

Наявність нульових морфем у сучасній мові є результатом розвитку словотвірної системи попередніх періодів. Поява нульових суфіксів, які були матеріально вираженими на ранніх етапах розвитку мови, зумовлена певними фонетичними та морфологічними процесами. Походження нульсуфіксальних морфем досліджували П. Білоусенко, Г. Ніколаєв, С. Самійленко, М. Шанський та інші.

У сучасному мовознавстві використання терміна «нульсуфіксація» та позначене ним явище не викликають заперечень. Однак тривалий час нульсуфіксація як різновид афіксального словотворення залишалася поза увагою науковців: такі іменники вважалися непохідними. Ця думка $\epsilon$ панівною у працях кінця XIX - першої половини XX ст.

Розпочавши у XX ст. дослідження нульсуфіксації та дериватів, утворених цим способом, учені використовували різні терміни для номінації відповідного явища: «безнаросткові слова» (Г. Головатий), слова, утворені «із самих пнів», «без наростків» (О. Синявський), «фонетико-морфологічний тип словотвору» (В. Виноградов, К. Левковська, Б. Головін), «безсуфіксні іменнники» (І. Матвіяс), «безсуфіксний спосіб» (Л. Гумецька), «регресивне словотворення» (І. Ковалик), «конверсія» (О. Смирницький, М. Докуліл), «безафіксний спосіб словотворення» (М. Шанський), «нульова афіксація» (3. Потіха). У 70-80-х роках минулого столяття остаточно утверджується і набуває в академічних граматиках східнослов'янських мов усе більшого поширення термін «нульсуфіксація» (В. Лопатін, Н. Клименко, О. Пінчук, Л. Родніна).

Зауважимо також, що першими (у 30-50-х роках XX ст.) назви «нульовий суфікс» (С. Смеречинський) та «нульовий наросток» (Ю. Шерех) використали українські вчені, т. зв. «мовознавцінаціоналісти», праці яких тривалий час не були доступними для філологів.

У сучасних дериватологічних працях, у підручниковій літературі нульсуфіксацію розглядають у складі суфіксального словотворення. Нульсуфіксальні деривати творяться найактивніше від дієслів (бігати біг, видихати - видих), меншою мірою - від прикметників (білий - біль, гладкий - гладь, блакитний - блакить).

Незважаючи на те, що питанням нульсуфіксації в межах суфіксальної системи іменників були присвячені окремі розробки східнослов'янської лінгвістики, на сьогодні окремі аспекти матеріально не 
вираженої суфіксації залишаються недослідженими. Зокрема, не виявлено кількісний склад нульсуфіксальних дериватів, що належать до різних шарів лексики, не з'ясовано питання лексико-словотвірної семантики похідних, утворених за допомогою нульового суфікса, не визначено роль та місце нульового форманта в різних лексико-словотвірних полях, мікрополях, до яких належить і мікрополе дериватів на позначення явищ природи та фізичних явищ. Це зумовило актуальність дослідження.

Учені зазначають, що «метрологічна народна термінологія одна 3 найбільш архаїчних, стійких лексичних груп української мови, значна частина лексем якої сягає ще праслов'янської доби» [3, с. 117]. У той же час метрологічна лексика української мови активно поповнюється новотворами, нерідко - запозиченнями, кальками 3 іноземних мов. Словотворення метрологічних назв практично не досліджене, оскільки вчені приділяли більшою мірою увагу питанням опису окремих лексикосемантичних груп у галузі метрології (О. Могила), особливостям побудови термінів-словосполучень (В. Нагіна), фрагментарно виконано дериваційний аналіз окремих слів 3 певним афіксом (Г. Аркушин, П. Білоусенко, В. Німчук).

Мікрополе на позначення метрологічних номенів містить такі девербативні нульсуфіксальні похідні чоловічого та жіночого роду: відлига (СУМ I, с. 601) - «значне потепління взимку або ранньою весною, що викликає часткове розтавання снігу, льоду», пор., відлигувати «розтавати внаслідок потепління»; відплив (с. 619) - «періодичне (двічі на добу) пониження рівня води в океанах і відкритих морях»; грім (с. 647) - «гуркіт i тріск, що супроводжують електричні розряди в атмосфері»; жара (II, c.509) - «гаряча літня пора; спека»; завія (III, с. 53) - «сильний вітер із снігом; хуга, завірюха»; розм. рідко заморозь (с. 220) - «незначний ранковий (нічний) мороз, що буває навесні або восени»; засуха (с. 339) «тривала відсутність дощу влітку, що призводить до висихання грунту і загибелі рослинності»; злива (с. 589) - «дуже сильний дощ»; розм. знегода (ВТСУМ, с. 377) - «непогода» від знегодитися; наморозь (СУМ V, с. 131) - «тонкий шар льоду, що утворився на поверхні землі і т. ін. в холодну сиру погоду»; приплив (VII, с. 711) тощо. Це угруповання місить також значну кількість нульсуфіксальних дериватів, які обмежені територією використання, а також застарілі слова, пор.: блиск (Гуц, с. 203) «блискавка» (блискати); діал. вилив (СУМ I, с. 421) - «повінь»; діал. відволога (ВТСУМ, с. 125) - «відлига» (пор. відвологнути, відвологти «стати вологим, пройнятися вологою»); відмок (СБГ, с. 54) - «відлига»; задувъ (Гол, с. 560) - «заметіль»; діал. залива (СУМ III, с. 183; Лем, с. 415; Жит, с. 26; Левч, с. 65; Мельн, с. 80) - «злива»; діал. замета (СУМ III, с. 205) - «заметіль: сильний вітер зі снігом; хуртовина»; занос (СУССГ, с. 83) - «завірюха, сніг із вітром»; затих (СБГ, с. 144) - «затишок» від затихати, затихнути; кра́са (СБГ, с. 231) - «веселка», певно, від діал. 
красєти «рябіти, миготіти» (там само) або від красний (СБГ, с. 231) «пістрявий, рябий»; діал. кура (СУМ IV, с. 406; Полт, с. 46) - «курява»; діал. навись (СУМ V, с. 31) - «навислий на гілках сніг»; діал. намерз (с. 125) - «іній; паморозь»; опадь і омет (Гриценко, с. 115) та окидь (СБГ, с. 363) - «легкий пухкий сніг на деревах у тиху погоду»; naдb (Моск, с. 55) - «шкідлива роса для тварин, посівів»; полом (СБГ, с. 443) «бурелом»; nomona (O II, с. 125) - «потоп»; розлива (Лис, с. 187) «потоп»; смерк (СУССГ, с. 193) - «сутінки»; хляпа (Бичко, с. 93) - «сніг 3 дощем» (хляпати); заст. затьмара (Тим I, с. 140) - «затемнення»; шквара (Левч, с. 48) - «спека»; обсув (ТехМірн, с. 129) - «зсув; сповзання верхнього шару землі схилом униз під діянням сили ваги» та ін.

У лексикографічних джерелах фіксуються поодинокі деривати, утворені поєднанням нульового суфікса та дієприкметникової основи, наприклад: діал. відталь (СУМ I, с. 647) - «відлига».

Мікрополе на позначення явищ природи, фізичних явищ містить невелику кількість суфіксальних утворень, серед яких чітко проявляються нульсуфіксальні деривати, а також i похідні 3 формантом -иця (-авиця, -овиця), що мають переважно народно-розмовний характер або архаїзувалися в процесі розвитку української мови, пор.: діал. вітряниия «буря», розм. сніговиця, діал. веселиия «веселка», діал. вогневиия «блискавка», діал. градовиця; діал. дуявиия «завія», діал. ляповиия «сніг 3 дощем», хурделиия тощо [див. 2, с. 121-122].

На загальний стан довкілля вказують іменники із суфіксом -ина: хуртовина (хуртова погода), блюхавина «сльота», свіжина «свіжість», розм. яснина «ясна погода», діал. теплина «тепла погода», розм., рідко холодина «те саме, що холоднеча», діал. мокрина «мокре літо», діал. суиина «тривала погода без дощів» тощо [1, с. 166].

Зрідка трапляються розглядані найменування з суфіксами -ок / -нок (заморозок, затінок, світанок), -ень / -вень (ливень, оповзень, діал. студень «холодний вітер»), -іль (заметіль) та деякі інші [5, с. 53-54, с. 66, с. $75 ; 6$, с. $126 ; 7$, с. 68$]$.

Подекуди іменники на позначення природних явищ використовуються в художній та публіцистичній літературі, наприклад: Календар степів з весни повертає на літо, у повітрі вже стоїть нестерпний тягар $і$ задуха (Дан, с. 53); Спека сушить і випалює трави (с. 74); пороша (Кв-Осн II, с. 601) - «сніг»; суша (III, с. 362) - «суха, жарка без дощів погода»; Загримів страшний грім (Нечуй, с. 221); nотоп (Новицький, с. 12); Вимита льодовиковими водами улоговина поступово покрилася буйною рослинністю $i$ завдяки сезонним розливам $і$ припливам Дніпра перетворилася на плавні (Чаб Атл, с. 9) тощо.

Питання щодо продуктивності / непродуктивності способів словотворення іменників із значенням явищ природи не порушується, 
оскільки на сьогодні це мікрополе $є$ закритим угрупованням. Однак можемо говорити про функціональне навантаження окремих суфіксів.

Отже, порівняно 3 матеріально вираженою суфіксацією нульсуфіксація посідає чільне місце у формуванні мікрополя дериватів на позначення явищ природи, фізичних явищ. Нульовий формант, сполучаючись із дієслівними (рідше - прикметниковими, дієприкметниковими) основами, створює потужну конкуренцію суфіксам -ина, -иця, -ок, а деривати 3 іншими суфіксами знаходяться на периферії розгляданої групи слів. Крім того, нульовий суфікс $є$ засобом творення похідних із широкою стилістичною гамою - це іменники літературного вжитку, розмовні та діалектні слова.

\section{Список скорочень назв використаних джерел}

Бичко - Бичко 3. М. Діалектна лексика Опілля / З. М. Бичко. - Львів : Фенікс, 1997. - 136 с.

ВТСУМ - Великий тлумачний словник сучасної української мови/ уклад. і голов. ред. В. Т. Бусел. - К. ; Ірпінь : ВТФ «Перун», 2003. - 1440 с.

Гол - Словник української мови Я. Ф. Головацького // Науковий збірник Музею української культури у Свиднику. - № 10. - 1982. - С. 311-612.

Гриценко - Гриценко П. Ю. Ареальне варіювання лексики / П. Ю. Гриценко ; відп. ред. І. Г. Матвіяс. - К. : Наукова думка, 1990. - 272 с.

Гуц - Словник гуцульських говірок // Гуцульщина. Лінгвістичні етюди / відп. ред. Я. Закревська. - К. : Наукова думка, 1991. - С. 90-270.

Дан - Данилевський Г. П. Чумаки : худож.-док. нарис / Г. П. Данилевський. - К. : Веселка, 1992. -110 с.

Жит - Паламарчук Л. С. Словник специфічної лексики говірки с. Мусіївки (Вчорайшенського району, Житомирської області) / Л. С. Паламарчук // Лексикографічний бюлетень. - Вип. VI. - К. : Видавництво АН УРСР, 1958. - С. 22-35.

Кв-Осн - Словник мови творів Г. Квітки-Основ'яненка : у 3-х т. - Т.1. - Харків, 1978. - 664 с.; Т.2. Харків, 1979. - 679 с.; Т.3. - Харків, 1979. - 689 с.

Левч - Опытъ русско-украинскаго словаря/ сост. М. Левченко. - К. : Типографія Губернскаго Управленія, 1874. - 190 с.

Лем - Верхратский І. Про говор галицких лемків / Іван Верхратский. - Львів : Збірник фільольогічної секції Наук. тов-ва ім. Т. Шевченка, 1902. - 490 с.

Лис - Лисенко П. С. Словник поліських говорів / П. С. Лисенко. - К. : Наукова думка, 1974. - 260 с.

Мельн - Мельничук О. С. Словник специфічної лексики говірки села Писарівки (Кодимського району, Одеської області) / О.С. Мельничук // Лексикографічний бюлетень. - Вип. ІІ. - К. : Видавництво АН УРСР, 1952. - С. 67-98.

Моск - Москаленко А. А. Словник діалектизмів українських говірок Одеської області / А. А. Москаленко. - Одеса : Вид-во Одеського пед. Інституту, 1958. - 78 с.

Нечуй - Нечуй-Левицький І. С. Кайдашева сім'я : Вибране / Іван Нечуй-Левицький. - К. : Рад. школа, 1990. - 416 с. : іл.

Новицький - Новицкий Я. П. Народная память о Запорожье. Предания и рассказы, собраннные в Екатеринославщине (1875-1905 г.) / Яков Новицкий. - Рига : Спридитис, 1990. - 118 с. (Репринтное воспроизведение издания 1911 года)

О - Онишкевич М. Й. Словник бойківських говірок / М. Й. Онишкевич. - К. : Наукова думка, 1984. Т.1. -496 с. ; Т.2. -515 c.

Полт - Сизько А. Т. Словник діалектної лексики сіл південно-східної Полтавщини / А. Т. Сизько. Дніпропетровськ : ДДУ, 1990. - 100 с.

СБГ - Словник буковинських говірок / за заг. ред. Н. В. Гуйванюк. - Чернівці : Рута, 2005. - 688 с.

СУМ - Словник української мови : в 11-и т. - К. : Наукова думка, 1970-1980.

СУССГ - Словник українських східнослобожанських говірок / К. Глуховцева, В. Лєснова,

I. Ніколаєнко, Т. Терновська, В. Ужченко. - Луганськ, 2002. - 234 с.

ТехМірн - Трихвилів Ю. Словник технічної термінології. Мірництво (проєкт) / Ю. Трихвилів, I. Зубков. - К. - Харків : Державне видавництво України, 1930. - 155 с.

Тим - Тимченко С. Русско-малороссійскій словарь : у 2-х т. / Свген Тимченко. - К. : Типография Имперскаго Университета св. Владімһра, 1897-1899.

Чаб Атл - Чабаненко В. А. Українська атлантида / В. А.Чабаненко. - Запоріжжя : КП «Запорізька міська друкарня «Дніпровський металург», 2006 - 405 с. 


\section{Література}

1. Білоусенко П. І. Нариси 3 історії українського словотворення (суфікс -ина) : [монографія] / П. І. Білоусенко, В. В. Німчук. - Запоріжжя - Ялта - Київ : ТОВ «ЛІПС» ЛТД, 2009. - 252 с.

2. Білоусенко П. І. Нариси 3 історії українського словотворення (суфікс -иця) : [монографія] / П. І. Білоусенко, В. В. Німчук. - Київ - Запоріжжя: ЗДУ, 2002. - 206 с.

3. Могила О. А. Ареальна і структурно-семантична характеристика назв хмар у говорах української мови / О. А. Могила // Українське мовознавство. - Вип. 9. - 1981. - С. 117 - 125.

4. Могила О. А. Карпато-поліські лексико-семантичні паралелі (на матеріалі метеорологічної лексики) / О. А. Могила // Структура i розвиток українських говорів на сучасному етапі : XV Республіканська діалектологічна нарада : тези доповідей і повідомлень. - Житомир, 1983. - С. 58-60.

5. Пінчук О. Ф. Словотвірна структура віддієслівних іменників сучасної української літературної мови / О. Ф. Пінчук // Морфологічна будова сучасної української мови. - К. : Наукова думка, 1975. C. $35-82$.

6. Полюга Л. М. Українська абстрактна лексика XIV - першої половини XVII с. / Л. М. Полюга. К. : Наукова думка, 1991. - 240 с.

7. Родніна Л. О. Суфіксальний словотвір іменників у сучасній українській мові / Л. О. Родніна // Словотвір сучасної української літературної мови. - К. : Наукова думка, 1979. - С. 57 - 118. 